\title{
AIR POLLUTION AND INCOME RELATIONSHIP IN TURKISH PROVINCES: A SPATIAL APPROACH
}

\author{
Abdurrahman Nazif ÇATIK* \\ Mehmet KARAÇUKA ${ }^{* *}$ \\ Gul HUYUGÜZEL-KIŞLA ***
}

\begin{abstract}
This paper investigates the existence of the Environmental Kuznets Curve (EKC) for Turkey by considering pollution spillovers among the provinces by using annual data covering the period 1990-2001. Spatial econometrics techniques are employed to account for pollution spillovers. Spatial interactions are measured by means of weight matrices based on contiguity and distance between the neighboring provinces. Our results show that exclusion of spatial heterogeneity among the regions may lead to specification bias in EKC estimations. The significance of pollution spillovers in the spatial estimates suggest that the relationship between pollution and per capita income is also affected by the localities of regions. Our results also imply that environmental quality cannot be sustained at the expense of neighboring regions. Therefore environmental policies should be accommodated by both regional and national policies to achieve sustainable development.
\end{abstract}

Keywords: Environmental Kuznets Curve, Pollution Spillovers, Spatial Econometrics, Turkey.

JEL Classification: O18, Q53, Q58.

\section{TÜRKIYYE'DEKİ BÖLGELER ARASINDA HAVA KİRLİLIĞİ VE GELİR İLIŞKİSI: MEKANSAL BİR YAKLAŞIM}

\section{Özet}

Bu çalışmada Türkiye için Çevresel Kuznets Eğrisinin (ÇKE) varlığı, bölgeler arasındaki kirlilik yayılımı dikkate alınarak 1990-2001 yıllarını kapsayan yıllık verilerle incelenmiştir. Kirliliğin yayılımının test

\footnotetext{
* Assoc. Prof. Ege University, Department of Economics, a.nazif.catik@ege.edu.tr

** Assoc. Prof. Ege University, Department of Economics, mehmet.karacuka@ege.edu.tr

*** Res. Assist. Ege University, Department of Economics, gul.kisla@ege.edu.tr
} 
edilmesinde mekansal ekonometrik yöntemlerden yararlanılmıştır. Mekansal bağlantıların ölçümünde komşu bölgeler arasındaki komşuluk ve uzaklık ilişkileri kullanılarak oluşturulan ağırlık matrislerinden yararlanılmıştır. Elde edilen sonuçlara gore bölgeler arasındaki mekansal heterojenliğin dikkate alınmaması Çevresel Kuznets Eğrisi tahminlerinde spesifikasyon hatalarına yol açmaktadır. Mekansal tahminlerde ortaya çıkan mekansal yayılmanın anlamlı oluşu ise kirlilik ve kişi başına gelir arasındaki ilişkinin aynı zamanda bölgelerin konumundan da etkilendiğini göstermektedir. Bununla birlikte elde edilen sonuçlar, çevre kalitesinin komşu bölgeler dikkate alınmadansağlanamayacağını ima etmektedir. $\mathrm{Bu}$ nedenle, sürdürülebilir kalkınmanın elde edilmesi için çevresel politikaların bölgesel ve ulusal düzeydeki politikalarla desteklenmesi gerekmektedir.

Anahtar kelimeler: Çevresel Kuznets Eğrisi, Kirlilik Yayılımı, Mekansal Ekonometri, Türkiye.

JEL Sınıflaması: O18, Q53, Q58.

\section{Introduction}

The crucial relationship between environmental policy and economic growth keeps being an important part of the global agenda as the concern for availability of natural resources grows in the recent years. This concern is magnified especially for developing countries of which, rapid population growth exacerbates the pressure on urbanization and industrialization.

One view on the effects of economic growth on environment is that growth requires more inputs and energy resources leading to more pollution and environmental degradation. This view gained publicity especially after the influential Club of Rome view ${ }^{1}$. Another view is that the relationship between environmental degradation and economic growth follows an inverted U-shaped pattern. This type of relationship is also known as environmental Kuznets curve (EKC), referring to the similar relationship between income inequality and economic development suggested by Kuznets ${ }^{2}$. This view argues that environmental quality deteriorates during the take-off stage of income growth and improves in later stages as an economy develops. The logic behind EKC is that in the first stage of industrialization the choice is towards economic growth in most cases when a trade-off occurs between growth and environment. Society values jobs and material output more than clean air and water. The growth rate is also higher in this stage and these results in more pollution and more extensive usage of natural resources ${ }^{3}$. However, as the economy develops and income rises over a threshold level, society values environment more and environmental policy measures can be implemented more efficiently. The increase of income can also allow the finance of clean energy resources. As a result, more environmental awareness in the society, slower growth rates, and more funds for the renewable energy resources gradually decrease the pollution level as an economy grows further than a threshold level. According to

\footnotetext{
D. H. Meadows et al., The Limits to Growth, New York, Universe Books, 1972.

S. Kuznets, "Economic Growth and Income Inequality", American Economic Review, 45(1), 1955, pp.1-28.

S. Dinda, "Environmental Kuznets Curve Hypothesis: A Survey”, Ecological Economics, 49(4), 2004, pp. 431-455.
} 
Grossman and Krueger ${ }^{4}$, there are three separate mechanisms for understanding the EKC. If there is an expansion of the economic activity without changing the structure of the economy, this will lead to an increased demand for energy and hence, total amount of pollution will rise. This is known as the scale effect. On the other hand, economic growth can increase or decrease the overall pollution through the composition effect. More clearly, the structure of the economy changes with the income growth. The pollution level increases with the evolution of the structure of the economy from agricultural to heavy industry. The environmental quality improves with the transformation of heavy industry into more light and clean industry. Finally, technique effect arising from the introduction of more modern technologies and higher income levels may lead to an increase in environmental quality ${ }^{5}$.

Turkey, seventeenth largest economy in the world, and still a developing country, has been in a process of rapid industrialization and urbanization especially since 1980's. According to the latest data by TURKSTAT countrywide urbanization is $62.7 \%$, quite below European Union (E.U.) and OECD average values. However, urbanization is rather fast with annual $2.3 \%$ increase in urban population. Urbanization rate is also higher than annual population growth (1.5 \%). The problems of population growth and industrial expansion in metropolitan regions also lead to an increase in the degree and complexity of air pollution problems. As a result, continuous countrywide air quality monitoring activities started in 1990 's ${ }^{6}$.

The aim of this study is to investigate the income-pollution relationship for Turkish provinces and to test if EKC hypothesis holds when spatial interactions are taken into consideration. The regional focus is important because of great regional variation in the population, urbanization, industrialization, and consumed energy composition, as well as differences in emissions and growth rates. Moreover, ignoring spatial relationships may lead to specification bias and wrong inferences about the relationship.

This paper is organized as follows. The next section briefly summarizes the literature on Environmental Kuznets Curve. Section 3 introduces our model used to investigate EKC in a spatial context. The data employed in the estimations are presented in Section 4 . Section 5 includes the empirical results of the study. Finally, Section 6 concludes the study.

\section{Overview of Literature on Environmental Kuznets Curve}

Given the importance of environmental policy for sustainable development, empirical literature on EKC has been continuously growing and the topic has not lost academic interest since the

4 G. M. Grossman and A. B. Krueger ${ }_{2}$ "Environmental Impacts of the North American Free Trade Agreement", NBER. Working paper, 3914, 1991

5 Grossman and Krueger ${ }_{2}$ Ibid.; T. Tsurumi and S. Managi, "Decomposition of the environmental Kuznets curve: scale, technique, and composition effects", Environmental Economics and Policy Studies, 11, 2010, pp. 19-36.

6 H. G. Özdilek, "An Analogy on Assessment of Urban Air Pollution in Turkey over the turn of the Millennium (19922001)", Environmental Monitoring and Assessment, 122(1-3), 2006, pp. 203-219. 
pioneering work of Grossman, and Krueger $(1991)^{7}$. Nevertheless, the main criticism stems from the usage of weak econometric techniques ${ }^{8}$.

The aim of this paper is not to review the whole EKC literature, since there are numerous studies covering the topic in detail ${ }^{9}$. However, most of the existing studies use cross-country data that raises compatibility and quality problem $\mathrm{s}^{10}$. In order to overcome this problem, Vincent ${ }^{11}$, Carson, Jeon and McCubbin ${ }^{12}$ and Asghari ${ }^{13}$ used single country data can help to eliminate the problems associated with comparing data from different countries, since there is single measurement methodology for both growth and environmental degradation levels. The evidence based on single country data yield also mixed results regarding the existence of EKC. Vincent (1997) investigates the existence of EKC using the six different water and air pollutants in Malaysia and find positive relationship between income and three pollutants, i.e. TSP, ammoniacal nitrogen and $\mathrm{pH}$. Carson et al. (1997) analyze the relationship between per capita income and seven different air pollutants across the 50 US states covering the period 1988-1994 and they do not find any evidence on the relationship between changes in income and changes in toxic emissions for all seven pollutants. Using the data for Iran covering the 1980-2008 periods, Asghari ${ }^{14}$ finds a U relationship between $\mathrm{CO} 2$ emission and economic growth in Iran in contrast to proposition of the $\mathrm{EKC}^{15}$

An important drawback of the studies in the literature is that they do not explicitly consider the pollution spillovers across regions. The transfer of pollution from one region that hosts the pollution resource from a neighboring region should also be considered. Theoretically, the reasons for cross-country spillovers are difficult to track down, however cross-provincial spillovers are quite intuitive. Stationary pollution resources such as power plants, residential and commercial energy consumption emit the majority of sulfur dioxide emissions. This sulfur dioxide is converted in the atmosphere into sulfates, which are a main component of fine particulate matter. The atmospheric transport of pollutants from any given source takes place through convection

7 G. M. Grossman and A. B. Krueger, Ibid.

8 D. I. Stern, “The Rise and The Fall of Environmental Kuznets Curve”, World Development, 32(8), 2004, pp. 14191439.

9 D. I. Stern et al. "Economic Growth and Environmental Degradation: A Critique of the Environmental Kuznets Curve",World Development, 24(7), 1996, pp. 1151-1160; D. I. Stern, "Progress on the Environmental Kuznets Curve?", Environment and Development Economics, 3(2), 1998, pp.173-196; S. Dasgupta et al., "Confronting the Environmental Kuznets Curve." Journal of Economic Perspectives, 16(1), 2002, pp. 147-168; S. Dinda, "Environmental Kuznets Curve Hypothesis: A Survey", Ecological Economics, 49(4),2004, pp. 431-455.

10 A. Rupasingha et al. "The Environmental Kuznets Curve for US counties: A Spatial Econometric Analysis with Extensions”, Papers in Regional Science, 83, 2004, pp. 407-424.

11 R. J. Vincent, “Testing for Environmental Kuznets Curves within a Developing Country”, Environment and Development Economics, 2(4), 1997, pp. 417-431

12 R. T. Carson et al., "The Relationship between Air Pollution Emissions and Income: US data”, Environment and Development Economics, 2(4), 1997, pp. 433-450

13 M. Asghari, "Environmental Kuznets Curve and Growth Source in Iran”, Panoeconomicus, 59(5), 2012, pp. 609-623

14 Ashgari, Ibid.

15 J. R. Vincent, a.g.m.; R. T. Carson et al. “The Relationship between Air Pollution Emissions and Income: US data”, Environment and Development Economics, 2(4), 1997, pp. 433-450 ; M. Asghari, Ibid. 
and diffusion by atmospheric turbulence and airflows. The pollutant plume moves away from the source and expands laterally.

Although this fact is already acknowledged in many studies, the empirical analysis based on spatial models is a recent attempt due to the lack of data and computational difficulties. The limited studies, which employs spatial econometric techniques are Rupasingha, Goetz, Debertin and Pagoulatos ${ }^{16}$ and Maddison ${ }^{17}$ investigating EKC for European countries and U.S.A. counties respectively. Those studies mainly corroborate the inverted U-shape pattern and per capita emissions are also found to be heavily influenced by the per capita emissions of neighbouring regions. Zheng, Yu, Wang, and Deng ${ }^{18}$ have estimated EKC models using the data for 30 provinces of China covering the period 1998 - 2010. The estimation results based on spatial dynamic panel models do not confirm the EKC relationship between CO2 intensity and growth. The spatial lag coefficient is found to be positive and statistically significant indicating that there is a spatial linkage between the neighboring provinces. The results further suggest that $\mathrm{CO} 2$ intensity is higher in the western regions compared to eastern regions of China.

Despite the distressing air pollution problems, the inhabitants facing in Turkey, little research has been carried out on the spatial and temporal evolution of air pollution episodes. Lise estimates $\mathrm{CO} 2$ emissions of main sectors by using energy consumption by decomposition analysis in a country level study. He finds that the link between energy and carbon emissions is a monotonic increasing one. This suggests that the absence of carbon policies, no significant reduction in $\mathrm{CO} 2$ emissions can be observed in the Turkish economy. He also finds that the largest increase in CO2 emissions is caused by the expansion of the economy. Another country level study is Soytas and Sar1, which investigates the long run Granger causality relationship between economic growth, carbon dioxide emissions and energy consumption. They find that emissions Granger cause energy consumption, but the reverse is not true. Elgin and Öztunalı investigate the relationship between the size of the informal sector as of GDP and the air pollutants, carbon dioxide and sulfur dioxide, in Turkey using the annual data from 1950 to 2009. According to the trivariate cointegration analysis, there is a long-run inverse U-shaped relationship between the emissions and the informal sector. They also employ multivariate cointegration analysis and found positive relationship between the emissions and the informal sector which shows the deregulation effect. On the other hand, there is a negative relationship between capital intensity and informal sector, confirming the scale effect ${ }^{19}$.

16 A. Rupasingha et al. "The Environmental Kuznets Curve for US counties: A Spatial Econometric Analysis with Extensions”, Papers in Regional Science, 83, 2004, pp. 407-424

17 D. Maddison, "Environmental Kuznets Curves: A Spatial Econometric Approach”, Journal of Environmental Economics and Management, 51(2), 2006, pp.218-230; D. Maddison, "Modelling sulphur emissions in Europe: A spatial econometric approach", Oxford Economic Papers, 59(4), 2007, pp. 726-743

18 X. Y. Zheng et al. "Identifying the Determinants and Spatial Nexus of Provincial Carbon Intensity in China: A Dynamic Spatial Panel Approach”, Regional Environmental Change 14, 2013, pp. 1651-1661.

19 W. Lise, "Decomposition of $\mathrm{CO}_{2}$ Emissions over 1980-2003 in Turkey", Energy Policy, 34 (14), 2006, pp.1841-1852; U.Soytas and R. Sar1, "Energy Consumption, Economic Growth, and Carbon Emissions: Challenges Faced by An EU Candidate Member”, Ecological Economics, 68(6), 2007, pp. 1667-1675; C. Elgin, and O. Öztunalı, "Environmental 
Akbostancı,Türüt-Aşık and Tunç investigatesEKC at both country and provincial levels using time series cointegration and panel data techniques. Based on time series analysis they find a long run relationship between pollution and income, however the result indicates a monotonically increasing function suggesting that EKC does not hold in Turkey. Even though they argue that the relationship between pollution and income follows an $\mathrm{N}$ shaped pattern, they find that all the provinces but one (Kocaeli) fall into the Kuznets section of the estimated relationship. Therefore it is not clear whether EKC hypothesis holds for Turkey based on the previous analysis ${ }^{20}$.

In this study, we extend the previous literature on spatial analysis income-pollution relationship within a developing country perspective. Employing spatial econometric techniques also allows us to test the existence of significant pollution spillovers among the neighboring regions.

\section{Model}

We use the following model to analyze empirical validity of the EKC hypothesis ${ }^{21}$.

$$
e m_{i t}=\alpha_{i}+\beta y_{i t}+\delta y_{i t}^{2}+\gamma X_{i t}+u_{i t}
$$

where $\mathrm{em}$ and $y_{i t}$ represent the pollutant and per capita income respectively. $X_{i t}$ is the vector of control variables that are assumed to have effect on environmental pollution and $u_{i t}$ is i.i.d. error term. Subscripts $\boldsymbol{i}$ and $\boldsymbol{t}$ represent the provinces and the time period, respectively. All variables enter the model in a natural log form.

The presence of the EKC hypothesis in the above model depends on the signs and significance of $\beta$ and $\delta$ parameters. If $\beta>0$ and $\delta<0$ and they are both significant, then there is an inverted $U$-shaped relationship between pollution and income per capita as indicated by the EKC relation. At the earlier stages of economic growth, a rise in per capita income leads to environmental pollution, therefore it has a negative impact on environmental quality. However, as income level reaches beyond a turning point, environmental quality starts to improve in the economy with the use of new and clean technologies in the production process. Hence per capita income and environmental quality become positively related.

A serious drawback of model in (1) is that air pollution resulting from everyday activities of the local units, especially, industrial plants and the burning of coal and exploitation of the other natural resources is assumed to be independent from the location-specific characteristics of regions. Therefore spatial interaction among the neighboring units should be taken into consideration in the estimation process. The same methodology is also adopted by Karacuka

Kuznets Curve for the Informal Sector of Turkey (1950-2009)", Panoeconomicus, 61(4), 2014, pp.471-485.

20 E. Akbostanc1 et al, "The Relationship between Income and Environment In Turkey: Is There an Environmental Kuznets Curve?", Energy Policy, 37(3), 2009, pp.861-867.

21 S. Dinda, Ibid. 
and Çatık in order to investigate inter-sectoral linkages in Turkey ${ }^{22}$. Exclusion of spatial effects has important implications for the econometric techniques. Omission of spatial interdependence may lead to specification bias and wrong inferences about the relationship.

In order to account for the effects of spatial heterogeneity in the data Spatial Autoregressive (SAR) and Spatial Error (SEM) models have been proposed by Anselin ${ }^{23}$, and widely used in the empirical literature ${ }^{24}$. In SAR models, spatial interactions are reflected by the inclusion of spatially weighted dependent variable as a regressor. In this case EKC equation is written as follows:

$$
e m_{i t}=\alpha_{i}+\beta y_{i t}+\delta y_{i t}^{2}+\gamma X_{i t}+\rho W e m_{i t}+u_{i t}
$$

where Wem refers to the spatially lagged emissions obtained through the multiplication of the emission level of each provinces with the spatial weight matrix $(W)$.

We define weight matrices used to estimate EKC in a spatial framework. In the context of our study we consider two different weight matrices: The binary contiguity matrix and inverse distance matrix. The binary contiguity matrix assumes that the spatial interaction only takes place between the regions sharing a common border. An element of the weight matrix is equal to 1 if the two regions have a common border and zero otherwise. In this case an element of the spatial contiguity matrix $w_{i j}$ is expressed as follows:

$$
w_{i j}=\left\{\begin{array}{l}
1 \text { If regions } i \text { and } j \text { has a common border, } \\
0 \text { otherwise. }
\end{array}\right.
$$

On the other hand inverse distance matrix allows regions to interact each other, but the extent of interaction is inversely related to distance between the city centers. Hence $w_{i j}$ is defined as,

$$
w_{i j}=1 / d_{i j},
$$

where $d_{i j}$ denotes the distance between the centre of provinces $\boldsymbol{i}$ and $\boldsymbol{j}$ measured in terms of kilometers. Additionally, all weight matrices are normalized with respect rows to define spatial dependency in terms of standardized values.

$\rho$ measures the existence and the magnitude of pollution spillovers. As pointed out by Anselin the spatial lag model may be considered as the formal specification for the equilibrium outcome of a spatial or social interaction process where the value of the dependent variable for one unit is instantaneously determined with that of the neighboring units. Hence, in our case positive and significant $\rho$ can be interpreted as an evidence for the positive pollution spillovers among the

22 M. Karaçuka and A. N. Çatık, "A Spatial Approach to Measure Productivity Spillovers of Foreign Affiliated Firms In Turkish Manufacturing Industries”, The Journal of Developing Areas, 46 (2), 2012, pp. 65-83.

23 Luc Anselin, Spatial Econometrics: Methods and Models, Dordrect, The Netherlands, Kluwer, 1988

24 See for example Luc Anselin and Rey. J. Florax, Advances in Spatial Econometrics. Methodology, Tools and Applications. Berlin, Springer-Verlag, 2004; Luc Anselin, Spatial Econometrics, In Palgrave Handbook of Econometrics, ed. Terence C. Mills and Kerry Patterson, Basingstoke, Palgrave McMillan, 2006. 
regions, i.e. environmental degradation level of a given region is connected with the pollution level of the contiguity regions.

Another way to incorporate spatial interaction is the use of SEM models, where spatial interactions are reflected through the spatially correlated error terms.

$$
\begin{aligned}
& e m_{i t}=\alpha_{i}+\beta y_{i t}+\delta y_{i t}^{2}+\gamma X_{i t}+u_{i t} \\
& u_{i t}=\lambda W u_{i t}+\varepsilon_{i t} \text { where } \varepsilon_{i t} \sim N\left(0, \sigma^{2} I_{n}\right)
\end{aligned}
$$

where $u_{i t}$ is the spatially autocorrelated error term and $\lambda$ is spatial autocorrelation coefficient. A spatial error model is a special case of a regression with a non-spherical error term where the interactions among the regions are mirrored by the off-diagonal elements of variance covariance matrix of residuals.

OLS methodology will not be appropriate for the estimation procedure of equation (5). First, the simultaneity problem due to the inclusion of spatial lag term in a SAR model, and second homoscedasticity assumption of OLS will not be valid for the SEM model, since the off-diagonal elements of residuals variance covariance matrix will not be zero. Anselin ${ }^{25}$ and Lee ${ }^{26}$ propose maximum likelihood estimations in order to overcome these problems that may lead inconsistent results. In this study we also employ maximum likelihood techniques based on Elhorst ${ }^{27}$.

\section{Data}

This paper uses annual panel data of Turkey's 58 provinces covering the period from 1990 to 2001. All data are obtained from Turkish Statistical Institute (TURKSTAT). The number of provinces in Turkey varies over the analyzed period. As an indicator of income level, we use real GDP per capita at 1987 prices. Investigation period of the study is determined by the availability of the data on real GDP per capita at provincial level ${ }^{28}$. There were 67 provinces in Turkey in the starting date 1990, however fourteen new provinces are split from other existing provinces over the investigation period. In order to eliminate this difference, the new provinces are added to the provinces where they separated. Given the unavailable pollution data for some of the east provinces, our analysis covers only 58 provinces. The limitation of data restricts our EKC analysis

25 L. Anselin, Ibid.;

26 L. Lee, "Asymptotic Distributions of Quasi-Maximum Likelihood Estimators for Spatial Autoregressive Models", Econometrica, 72(6), 2004, pp. 1899-1925

27 P. Elhorst, "Specification and Estimation Panel Data Models", International Regional Review, 26(3), 2003, pp. 244268.

28 The unavailability of up-to-date regional income variable required for the estimation of the EKC regressions is the main limitation of the study. Per capita regional GDP is only available for the period 1990-2001. There is no regional income data between 2001-2005. The regional Gross Value Added data published by TURKSTAT can be employed as a proxy for the per capita income, however this dataset contains the observations of 26 regions for the period 2007-2011 at NUTS2 level, it may not allow us to conduct statistically meaningful analysis. 
with the only two air pollutants, $\mathrm{SO}_{2}$ (milligram in metric cube) and suspended particulate matter $\left(\mathrm{PM}_{10}\right) \cdot \mathrm{PM}_{10}$ is measure of particles in the atmosphere with a diameter of less than ten or equal to a nominal 10 micrometers. It contains dust, soot and other tiny bits of solid materials that are released into the air.

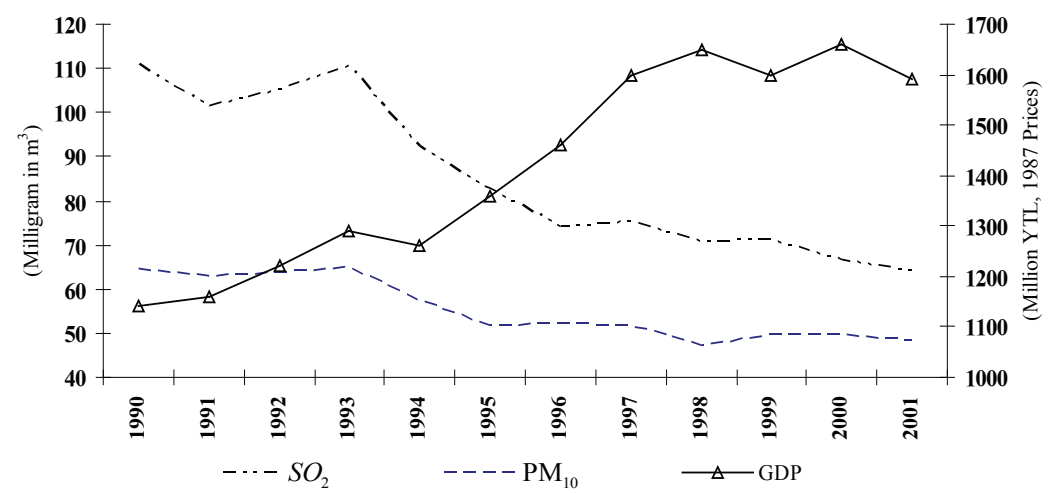

Figure I. Emission Indicators and GDP in Turkey: 1990-200 I

Source: TURKSTAT, www.turkstat.gov.tr.

Along with per capita income, we include two additional variables to control for the effects of other determinants of pollution: Population density and share of manufacturing industry. Population density is defined as a proportion of total provincial population to the land area in terms of $\mathrm{km}^{2}$ and whereas the share of manufacturing is obtained by dividing total output of the manufacturing sector by the total GDP of the province. Expected parameter sign for both variables are positive, in line with the stylized fact that highly industrialized and populated areas are likely to be more polluted.

As a preliminary evidence for the EKC relationship, sulphur dioxide and particulate matter concentrations of Turkey are illustrated in Figure 1, along with GDP at 1987 prices. The figure shows that between 1990 and 1994, GDP growth in Turkish economy was accompanied with increases in the emissions. However, these two indicators started to move in opposite directions when pollution indicators started declining after 1994 at national level. Table 1 shows this evolution at provincial level. The decline in $\mathrm{SO}_{2}$ and $\mathrm{PM}_{10}$ emissions are very noteworthy in industrialized metropolitan cities such as Ankara, Bursa, Istanbul, Izmir and Kocaeli. An important factor for declining trend in the air pollution can be attributed to the major changes in energy use in production and heating. Since the midst of 1990s natural gas has become a widely available energy source for electricity and residential heating in most of the metropolitan cities, in which coal had been primary energy resource. In order to illustrate this fact the energy consumption by primary energy resources is presented between the years 1970 and 2005 in terms of Tons of Equivalent Petroleum (TEP) (see Figure 2). Total primary energy consumption in Turkey has an 
increasing trend and risen to 89.099 million TEP by the year of 2005. Crude oil constitutes the highest share in the energy consumption with $36.1 \%$, which is followed by natural gas with $27.7 \%$ and coal (the total of hard coal and lignite) with $24.5 \%$. The growth in the consumption of natural gas in recent years is especially noteworthy and reflects the structural change in the energy policy of the government. In line with the passing of Electricity Market Law and Natural Gas Market Law in 2001, private investors entered into electricity and natural gas market. In collaboration with foreign affiliates, they have established natural gas distribution companies for residential heating and also built thermal power plants via build-operate-transfer and build-operate models using natural gas to produce electricity under the control of Energy Market Regulatory Authority $(\text { EMRA })^{29}$.

Table I. Descriptive Properties of Some Selected Provinces in Turkey

\begin{tabular}{|c|c|c|c|c|c|c|c|c|c|c|c|}
\hline & & \multicolumn{2}{|c|}{ (1987 Prices, YTL) } & \multicolumn{2}{|c|}{$\begin{array}{l}\text { Population } \\
\quad(1000)\end{array}$} & \multicolumn{2}{|c|}{$\begin{array}{c}\mathrm{PM}_{10}(\mu \mathrm{g} / \\
\mathrm{m} 3)\end{array}$} & \multicolumn{2}{|c|}{$\mathrm{SO}_{2}(\mu \mathrm{g} / \mathrm{m} 3)$} & \multicolumn{2}{|c|}{$\begin{array}{l}\text { Share of Manu- } \\
\text { facturing Indus- } \\
\text { try (\%) }\end{array}$} \\
\hline & & 1990 & 2001 & 1990 & 2001 & 1990 & 2001 & 1990 & 2001 & 1990 & 2001 \\
\hline 1 & İstanbul & 17333961 & 23607618 & 7196 & 10650 & 118 & 59 & 242 & 62 & 31.593 & 28.907 \\
\hline 2 & Ankara & 6579837 & 8471367 & 3236 & 4503 & 103 & 44 & 170 & 30 & 15.393 & 13.048 \\
\hline 3 & İzmir & 6338207 & 8381585 & 2695 & 3468 & 77 & 41 & 96 & 32 & 30.553 & 31.140 \\
\hline 4 & Kocaeli & 3643984 & 5035541 & 920 & 1250 & 109 & 49 & 198 & 63 & 57.855 & 58.550 \\
\hline 5 & Bursa & 3322877 & 4601273 & 1596 & 2208 & 89 & 39 & 185 & 61 & 34.931 & 39.187 \\
\hline 6 & Adana & 3016540 & 3190488 & 1714 & 2356 & 44 & 15 & 22 & 26 & 27.499 & 27.403 \\
\hline 7 & Manisa & 2247267 & 3007258 & 1154 & 1266 & 46 & 42 & 65 & 45 & 13.071 & 20.334 \\
\hline 8 & Antalya & 1902320 & 2956989 & 1132 & 1820 & 57 & 62 & 29 & 45 & 7.128 & 6.464 \\
\hline 9 & Mersin & 2348656 & 2948871 & 1267 & 1710 & 41 & 74 & 44 & 68 & 30.040 & 26.647 \\
\hline 10 & Konya & 1957269 & 2272249 & 1860 & 2502 & 95 & 48 & 216 & 43 & 19.301 & 18.273 \\
\hline 11 & Denizli & 1159241 & 1780652 & 751 & 860 & 54 & 69 & 100 & 99 & 26.849 & 40.857 \\
\hline 12 & Hatay & 1429209 & 1731119 & 1110 & 1268 & 80 & 40 & 82 & 44 & 18.451 & 14.306 \\
\hline 13 & Gaziantep & 1504936 & 1685811 & 1010 & 1436 & 69 & 60 & 115 & 88 & 19.550 & 22.417 \\
\hline 14 & Muğla & 1114967 & 1658266 & 563 & 738 & 35 & 40 & 47 & 90 & 17.743 & 19.220 \\
\hline 15 & Samsun & 1426481 & 1595304 & 1161 & 1204 & 55 & 29 & 132 & 43 & 15.396 & 15.242 \\
\hline 16 & Balıkesir & 1452161 & 1594430 & 974 & 1084 & 44 & 45 & 70 & 45 & 18.012 & 19.237 \\
\hline 17 & Aydın & 1311294 & 1565776 & 825 & 965 & 52 & 25 & 50 & 40 & 8.875 & 8.721 \\
\hline 18 & Eskişehir & 991376 & 1512380 & 641 & 710 & 43 & 40 & 172 & 46 & 25.384 & 24.763 \\
\hline 19 & Tekirdağ & 893035 & 1455139 & 469 & 648 & 60 & 18 & 82 & 104 & 24.952 & 43.500 \\
\hline 20 & Kayseri & 926315 & 1332039 & 944 & 1071 & 79 & 70 & 161 & 62 & 18.458 & 18.624 \\
\hline
\end{tabular}

Source: TURKSTAT, www.turkstat.gov.tr.

29 K. Kaygusuz, "Energy Use and Air Pollution Issues in Turkey", Clean, 35(6), 2007, pp. 539-547. 


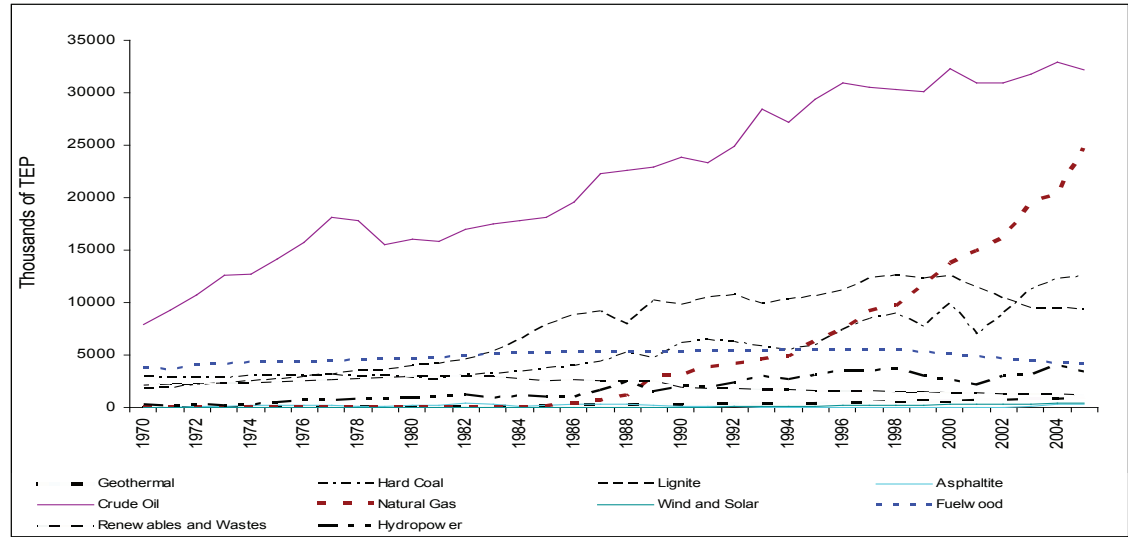

Figure 2. Energy Consumption by Primary Energy Resources in Turkey: 1970-2005

Source: Turkish Ministry of Energy, www.energy.gov.tr.

This transformation in the energy market is more apparent in terms of composition of energy usage in the electricity production (see Figure 3). As the figure shows, the use of natural gas as a less pollutive gas compared to coal and oil has increased considerably in 1990s. Even though the use of coal also shows an increasing trend over the investigation period, natural gas has become a major resource for electricity generation. In particular, by the year of 2005, 73444.9 Gigawatt hours (GWh), approximately $50 \%$ of country's electricity, is generated by thermal stations operating with natural gas.

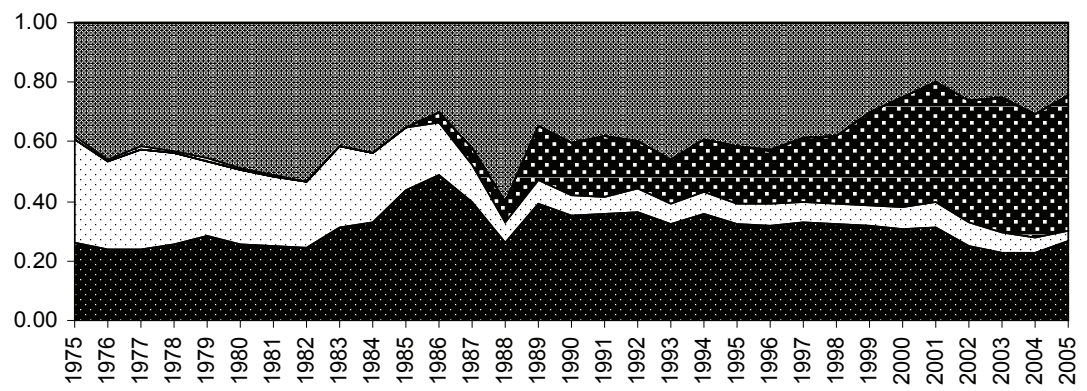

- Coal $\square$ Liquid Fuels Natural Gas . Renewable Wastes 图 Hydropower 图 Geothermal and Wind

Figure 3. Annual Development of Turkey's Electricity Generation by Primary Energy Resources

Source: Turkish Electricity Transmission Company, www.teias.gov.tr. 
In addition to substitution of natural gas in the heating and electricity generation, a decline in concentrations of $\mathrm{SO}_{2}$ and $\mathrm{PM}_{10}$ can also attributed to the major changes in the fuel types used in the residential areas: domestic coal with high sulphur content has been prohibited for heating and replaced by imported coal with a lower sulphur content. Despite the above mentioned improvement in the air quality, air pollution is still a major concern for Turkey. Average concentrations of $\mathrm{SO}_{2}$ and $\mathrm{PM}_{10}$ have remained above the World Health Organization (WHO) reference values of 20 and $50 \mathrm{mg} / \mathrm{m}^{3}$, respectively. In particular, the average concentrations of $\mathrm{SO}_{2}$ and $\mathrm{PM}_{10}$ in 2001 are $86.45 \mathrm{mg} / \mathrm{m}^{3}$ and $63.40 \mathrm{mg} / \mathrm{m}^{3}$.

\section{Empirical Results}

Our estimation procedure is based on two steps. First, to investigate the existence of EKC we estimate the equation (1) without spatial interactions. Second, the spatial effects are introduced by using SAR and SEM models to show whether the interaction among the regions has any impact in explaining income and pollution relation.

Table 2. Panel Data OLS Estimation Results for $\mathrm{SO}_{2}$ and $\mathrm{PM}_{10}$

\begin{tabular}{|c|c|c|c|c|}
\hline & \multicolumn{2}{|c|}{$\mathrm{SO}_{2}$} & \multicolumn{2}{|c|}{$\mathrm{PM}_{10}$} \\
\hline & (I) & (II) & (III) & (IV) \\
\hline & Baseline Model & Extended Model & Baseline Model & Extended Model \\
\hline$\alpha$ & $\begin{array}{l}-0.4844^{*} \\
(0.2516)\end{array}$ & $\begin{array}{l}-0.4553 \\
(0.3251)\end{array}$ & $\begin{array}{l}-0.3441 \\
(0.2636)\end{array}$ & $\begin{array}{l}-0.4551 \\
(0.1957)\end{array}$ \\
\hline$\beta$ & $\begin{array}{l}0.0845^{\star *} \\
(0.036)\end{array}$ & $\begin{array}{l}0.08864^{\star *} \\
(0.0464)\end{array}$ & $\begin{array}{l}0.0600^{\star} \\
(0.036)\end{array}$ & $\begin{array}{l}0.0765^{\star * *} \\
(0.0280)\end{array}$ \\
\hline$\delta$ & $\begin{array}{l}-0.0033^{* * *} \\
(0.0013)\end{array}$ & $\begin{array}{l}-0.0035^{\star *} \\
(0.0016)\end{array}$ & $\begin{array}{l}-0.0023^{*} \\
(0.0013)\end{array}$ & $\begin{array}{l}-0.0028^{* * *} \\
(0.0010)\end{array}$ \\
\hline$\gamma_{1}$ & & $\begin{array}{l}0.0428^{\star * *} \\
(0.0156)\end{array}$ & & $\begin{array}{l}0.0036^{\star * *} \\
(0.0012)\end{array}$ \\
\hline$\gamma_{2}$ & & $\begin{array}{l}0.0015 \\
(0.0033)\end{array}$ & & $\begin{array}{l}0.0013 \\
(0.0017)\end{array}$ \\
\hline S.E. & 0.3898 & 0.38796 & 0.3144 & 0.3126 \\
\hline
\end{tabular}

Note: ${ }^{*},{ }^{* *}$ and ${ }^{* * *}$ denote significant at $10 \%, 5 \%$ and $1 \%$ respectively. Standard errors of the parameters are given in parentheses.

Panel estimates with no spatial interaction are presented in Table 2. In the estimation of panel models without spatial interaction the usual steps are followed. First the models are estimated in both pooled and fixed effect form, and then to make a decision between those models Wald test is conducted. In case of selection of fixed effects over pooled model, we estimate the model 
using random effect. Decision between fixed and random effects is determined by Hausman specification test.

According to results, fixed effects are found to be the most appropriate specification in all cases. First we note that baseline models presented in columns (I) and (III) confirm the existence of pure EKC hypothesis between per capita income and emission variables. The respective coefficients of per capita GDP and its squared product in line with the predictions of EKC corroborating inverted U-shaped relationship between per capita income and the emissions. As for the control variables, population density is found to be positive and significant at 1 percent significance level supporting the view that population growth is likely to lead higher emission level in the provinces. However, we obtain insignificant parameters for the share of manufacturing industry $\gamma_{2}$ as far as both pollutants $\mathrm{S}_{2}$ and $\mathrm{PM}_{10}$ are concerned. This may suggest that air pollution may not be mainly driven by industrial activities in some of the provinces. The other local factors such as transportation, the burning of coal and exploitation of the natural resources may play a significant role in the rise of emission level.

Table 3. Tests of spatial dependence: Baseline Model

\begin{tabular}{|c|c|c|c|c|}
\hline & $\begin{array}{l}\mathrm{SO}_{2} \\
\text { Binary Contiguity } \\
\text { Matrix }\end{array}$ & $\begin{array}{l}\text { Inverse Distance } \\
\text { Matrix }\end{array}$ & $\begin{array}{l}\text { PM } \\
\text { Binary Contiguity } \\
\text { Matrix }\end{array}$ & $\begin{array}{l}\text { I } \\
\text { Inverse Distance } \\
\quad \text { Matrix }\end{array}$ \\
\hline & (I) & (II) & (III) & $\overline{(I V)}$ \\
\hline LM-Lag & 85.7024 & 82.5605 & 19.1600 & 27.8933 \\
\hline Marginal Probability & $(0.0000)$ & $(0.0000)$ & $(0.0000)$ & $(0.0000)$ \\
\hline LM-Error & 89.4262 & 76.0952 & 17.3129 & 26.5096 \\
\hline Marginal Probability & $(0.0000)$ & $(0.0000)$ & $(0.0000)$ & $(0.0000)$ \\
\hline Robust LM-Lag & 11.6251 & 19.3527 & 8.3334 & 8.4420 \\
\hline Marginal Probability & $(0.0007)$ & $(0.0000)$ & $(0.0039)$ & $(0.0030)$ \\
\hline Robust LM-Error & 15.3490 & 12.8874 & 6.4863 & 2.1341 \\
\hline Marginal Probability & $(0.0001)$ & $(0.0003)$ & $(0.0109)$ & $(0.1441)$ \\
\hline
\end{tabular}

Note: Marginal Probabilities are given in parentheses. LM-Lag and LM-Error statistics are distributed as $\chi^{2}(1)$ with the critical value 6.640 .

After the panel estimates, to determine the presence and the form of spatial interaction among the neighboring regions, LM-Error and LM-Lag tests and their robust counterparts are computed. Following Anselin and Florax and Florax et al. ${ }^{30}$ we employ

30 Luc Anselin and Rey. J. Florax, a.g.m.; R.J. Florax et al. "Specification Searches In Spatial Econometrics: The Relevance of Hendry's Methodology”, Regional Science and Urban Economics, 33(23), 2003, s. 557-579. 
the following model selection procedure to find which specification, SAR or SEM, is the more appropriate: If LM-Lag test is significant but not the LM-Error, the SAR model is chosen as the appropriate model and vice versa. In case of significance of both LM tests, the decision is made on the basis of Robust version of LM tests. If only one of the Robust-LM test rejects the null hypothesis of spatial autocorrelation, that model have to be preferred. If both Robust-LM tests are significant, the results of the model with higher Robust-LM statistics should be considered.

Table 4. Tests of spatial dependence: Extended Model

\begin{tabular}{|c|c|c|c|c|}
\hline & \multicolumn{2}{|c|}{$\mathrm{SO}_{2}$} & \multicolumn{2}{|c|}{$\mathrm{PM}_{10}$} \\
\hline & $\begin{array}{c}\text { Binary Contiguity } \\
\text { Matrix }\end{array}$ & $\begin{array}{c}\text { Inverse Distance } \\
\text { Matrix }\end{array}$ & Contiguity Matrix & $\begin{array}{c}\text { Inverse Distance } \\
\text { Matrix }\end{array}$ \\
\hline & (I) & (II) & (III) & (IV) \\
\hline LM-Lag & 85.4122 & 82.1113 & 20.4881 & 29.4949 \\
\hline Marginal Probability & $(0.0000)$ & $(0.0000)$ & $(0.0000)$ & $(0.0000)$ \\
\hline LM-Error & 89.1137 & 75.3447 & 18.9636 & 28.4919 \\
\hline Marginal Probability & $(0.0000)$ & $(0.0000)$ & $(0.0000)$ & $(0.0000)$ \\
\hline Robust LM-Lag & 10.5664 & 22.1556 & 4.0110 & 5.0223 \\
\hline Marginal Probability & $(0.0012)$ & $(0.0000)$ & $(0.0452)$ & $(0.0240)$ \\
\hline Robust LM-Error & 14.2679 & 15.3890 & 2.4864 & 2.7206 \\
\hline Marginal Probability & $(0.0002)$ & $(0.0001)$ & $(0.1148)$ & $(0.0956)$ \\
\hline
\end{tabular}

Note: Marginal Probabilities are given in parentheses. LM-Lag and LM-Error statistics are distributed as $\chi^{2}(1)$ with the critical value 6.640 .

LM-Error and LM-Lag test statistics reported in Table 3 and Table 4 are found to be significant at 1 percent significance level. This implies the presence of significant spatial heterogeneity in the income and pollution relationship. In other words, OLS estimates presented in Table 5.1 may include a specification bias due to the lack of spatial interactions among the regions; therefore they do not provide complete account of the EKC. The decision procedure described above also 
indicates that SAR model appears to be superior in most cases. The only exception occurs for $\mathrm{SO}_{2}$ when the binary contiguity matrix is employed in the LM tests. In this case since the Robust LM-Error (15.34) is greater than Robust LM-Lag (11.63), SEM model appears to be the more appropriate model.

Table 5. Spatial Panel Estimation Results for $\mathrm{SO}_{2}$

\begin{tabular}{|c|c|c|c|c|c|c|c|c|}
\hline & & Binary Cont & iguity Matı & & & Inverse Di & stance Mat & \\
\hline & (I) & (II) & (III) & (IV) & $(\mathrm{V})$ & (VI) & (VII) & (VIII) \\
\hline & SAR & SEM & SAR & SEM & SAR & SEM & SAR & SEM \\
\hline$\beta$ & $0.0987^{\star *}$ & $0.1418^{\star * *}$ & $0.0994^{* * *}$ & $0.0969^{\star}$ & $0.0880^{\star *}$ & $0.0802^{\star \star}$ & $0.0823^{\star}$ & $0.0904^{\star}$ \\
\hline & $(0.0444)$ & $(0.0475)$ & $(0.0368)$ & $(0.0555)$ & $(0.0432)$ & $(0.0432)$ & $(0.0479)$ & $(0.0543)$ \\
\hline$\delta$ & $-0.0039^{* *}$ & $-0.0055^{\star * *}$ & $-0.0043^{\star}$ & $-0.0041^{\star}$ & $-0.0034^{* * *}$ & $-0.0032^{\star *}$ & $-0.0033^{* *}$ & $-0.0351^{\star * *}$ \\
\hline & $(0.0016)$ & $(0.0017)$ & $(0.0024)$ & $(0.0023)$ & $(0.0015)$ & $(0.0015)$ & $(0.0016)$ & $(0.0131)$ \\
\hline$\gamma_{1}$ & & & $0.0116^{* * *}$ & $0.007^{\star *}$ & & & $0.0122^{* * *}$ & $0.01269^{* * *}$ \\
\hline & & & $(0.0045)$ & $(0.0032)$ & & & $(0.0044)$ & $(0.0328)$ \\
\hline$\gamma_{2}$ & & & $0.0211^{*}$ & $0.028^{*}$ & & & 0.0150 & $0.023^{*}$ \\
\hline & & & $(0.0114)$ & $(0.015)$ & & & $(0.0122)$ & $(0.013)$ \\
\hline$\rho$ & $0.1880^{* * *}$ & & $0.144^{\star * *}$ & & $0.4020^{\star * *}$ & & $0.305^{\star \star \star}$ & \\
\hline & $(0.0665)$ & & $(0.0486)$ & & $(0.0980)$ & & $(0.133)$ & \\
\hline$\lambda$ & & $0.4350^{\star * *}$ & & $0.441^{\star * *}$ & & $0.5650^{* * *}$ & & 0.492 \\
\hline & & $(0.0563)$ & & $(0.0559)$ & & $(0.0864)$ & & 0.1003 \\
\hline S.E. & 0.3747 & 0.3770 & 0.3738 & 0.3701 & 0.3659 & 0.3856 & 0.3826 & 0.3651 \\
\hline Log-Lik. & -316.209 & -317.137 & -308.872 & -315.784 & -329.841 & -327.795 & -321.385 & -318.473 \\
\hline
\end{tabular}

Notes: ${ }^{*}{ }^{* *}$ and ${ }^{* * *}$ denote significant at $10 \%, 5 \%$ and $1 \%$ respectively. Asymptotic standard errors of the parameters are given in parentheses.

Despite the results of specification tests outlined above, we also present the results of the alternative spatial models in Table 5 and Table 6 . First we note that inclusion of spatial dependency among the regions improves the fit of the model, as observed by the decrease in the standard errors of regressions. Second, spatial coefficient of SAR $(\rho)$ and SEM models $(\lambda)$, are both positive and significant, suggesting the existence of pollution spillovers among the neighbors, i.e. environmental degradation levels of the contiguity regions are inter-connected. The results obtained from the models are also robust to the change in alternative weight matrix specifications. Conventional models neglect this kind of spillover effects that may cause misleading results in the estimations. 
Spatial effects are found to be more pronounced when regressions are estimated with inverse distance matrix rather than the binary contiguity matrix. This suggests that the extent of spillovers among the regions can be better modeled by the distance between the city centers.

Spatial error parameters found to be larger than spatial lag parameters in all emission estimates. Among the other control variables, population density is still significant at $1 \%$ significance level. It is also interesting to note that the parameters on the share of manufacturing industry in some regressions turn into significant at 10 percent level after the inclusion of variables supporting the positive correlation between pollution and industrial activity. On general, we find that spatial interaction variables dominate the effects of control variables.

Table 6. Spatial Panel Estimation Results for $P M_{10}$

\begin{tabular}{|c|c|c|c|c|c|c|c|c|}
\hline & \multicolumn{4}{|c|}{ Binary Contiguity Matrix } & \multicolumn{4}{|c|}{ Inverse Distance Matrix } \\
\hline & (I) & (II) & (III) & (IV) & $(\mathrm{V})$ & $(\mathrm{VI})$ & (VII) & (VIII) \\
\hline & SAR & SEM & SAR & SEM & SAR & SEM & SAR & SEM \\
\hline \multirow[t]{2}{*}{$\beta$} & $0.0698^{\star}$ & $0.0888^{* *}$ & $0.0754^{\star *}$ & $0.0901^{\star *}$ & $0.0643^{*}$ & $0.0587^{\star}$ & $0.0685^{\star}$ & $0.0653^{\star}$ \\
\hline & $(0.0359)$ & $(0.0377)$ & $(0.0356)$ & $(0.0375)$ & $(0.0352)$ & $(0.0345)$ & $(0.0351)$ & $(0.0346)$ \\
\hline \multirow[t]{2}{*}{$\delta$} & $-0.0027^{\star *}$ & $-0.0034^{\star *}$ & $-0.0029^{\star *}$ & $-0.0032^{\star *}$ & $-0.0025^{\star *}$ & $-0.0023^{*}$ & $-0.0026^{\star *}$ & $-0.0025^{\star *}$ \\
\hline & $(0.0013)$ & $(0.0013)$ & $(0.0013)$ & $(0.0013)$ & $(0.0013)$ & $(0.0012)$ & $(0.0012)$ & $(0.0012)$ \\
\hline \multirow{2}{*}{$\gamma_{1}$} & & & $0.0413^{\star * *}$ & $0.0345^{\star * *}$ & & & $0.0318^{* * *}$ & $0.0365^{* * *}$ \\
\hline & & & $(0.0114)$ & $(0.0115)$ & & & $(0.0113)$ & $(0.0119)$ \\
\hline \multirow{2}{*}{$\gamma_{2}$} & & & $0.0086^{*}$ & 0.0079 & & & $0.0092^{\star}$ & $0.0089^{\star}$ \\
\hline & & & $(0.0044)$ & $(0.0052)$ & & & $(0.0055)$ & $(0.0052)$ \\
\hline \multirow[t]{2}{*}{$\rho$} & $0.1430^{\star *}$ & & $0.1392^{\star *}$ & & $0.3370^{\star * *}$ & & $0.303^{\star \star *}$ & \\
\hline & $(0.0704)$ & & $(0.07)$ & & $(0.1165)$ & & -0.1161 & \\
\hline \multirow[t]{2}{*}{$\lambda$} & & $0.4250^{* * *}$ & & $0.383^{* * *}$ & & $0.5230^{\star * *}$ & & $0.448^{\star * *}$ \\
\hline & & $(0.0570)$ & & $(0.0596)$ & & $(0.0944)$ & & -0.1085 \\
\hline S.E. & 0.3030 & 0.2995 & 0.3005 & 0.2985 & 0.2977 & 0.3066 & 0.2972 & 0.3051 \\
\hline Log-Lik. & -166.682 & -156.609 & -159.174 & -152.571 & -168.312 & -167.765 & -162.334 & -163.404 \\
\hline
\end{tabular}

Notes: ${ }^{*},{ }^{* *}$ and ${ }^{* * *}$ denote significant at $10 \%, 5 \%$ and $1 \%$ respectively. Asymptotic standard errors of the parameters are given in parentheses.

According to our spatial analyses, there is evidence that EKC has an inverted U- shaped. The turning points for SO2 and PM10 emissions are calculated as \$2597 and \$2506 for the SAR models $^{31}$. In case of SO2 emissions, the pollution increases with the income per capita increases

31 Following previous literature, the turning point is calculated by the following formula: $\operatorname{turn}=\exp (-\beta / 2 \delta)$. In order to compare turning points with the previous studies, they are converted into 2001 US\$. 
between the income per capita levels of $\$ 0-\$ 2597$. Beyond the level of $\$ 2597$, the pollution decreases with the income per capita increases. 39 provinces out of 58 are located in the first phase of the inverse $\mathrm{U}$-shaped EKC and the rest of the total provinces are located in the second phase of the inverted U-shaped. Some provinces like Ağrı, Bingöl and Bitlis are in the first phase and very far away from turning points with their per capita income while Balıkesir, Burdur, Hatay and Rize are all located nearly under the turning point of 2597. Some provinces like Adana, Ankara, İzmir and İstanbul are located in the second phase of the EKC. While Adana is very near to the turning point with the per capita income of \$2656; Kocaeli, İstanbul and İzmir are very far away from the turning point. These finding are consistent with the findings of PM10 emissions. According to these results, it can be stated that low-income provinces are generating more pollution with the low quality coals and older technologies. On the other hand, as the usage of natural gas and coals with lower sulphur contents become widespread and stringent emission controls become popular in the high-income provinces, the concentrations of the SO2 and PM10 are expected to decrease over time.

\section{Conclusion}

In this paper we analyze the relationship between income and air pollution in Turkey by considering pollution spillovers among neighboring provinces. For this purpose spatial econometric models are employed. Spatial interactions are measured by means of weight matrices based on contiguity and distance between the neighboring units. Our estimates indicate that the relationship between income and pollution follows an inverted U-shape as indicated by EKC hypothesis. We find significant EKC relationship for two local air pollutants, $\mathrm{SO}_{2}$ and $\mathrm{PM}_{10}$. This relationship is robust to the inclusion of other determinants of pollution. The turning points calculated from the spatial models indicate that most of the provinces are still located in the first phase of EKC, i.e. pollution is still increasing with the per capita income growth.

We find that spatial econometric techniques improve the understanding of the relationship between pollution and per capita income growth. Our results suggest that exclusion of spatial heterogeneity among the regions may lead to specification bias in EKC estimations. The significance of pollution spillovers among the regions indicates the existence of unobservable local determinants in the income and pollution relationship.

Our study also shows that environmental quality cannot be sustained at the expense of neighboring regions; therefore environmental policies should be accommodated by both regional and national policies to achieve sustainable development. This result has important policy implications in a country where income distribution shows inequality patterns among the regions. Neither central governments nor local administrations can implement pollution strategies independently. Successful strategies should be based on a master plan that all administrations participate and implement. Less developed regions should be supported to encourage greener energy resources. The decline in the pollution levels due to higher share of natural gas as a primary energy resource 
gives promising results, however air quality indicators are still far above satisfactory levels. Government and local administrations need to implement policies to reduce levels of pollution and $\mathrm{SO}_{2}$ emissions in order to avoid irreversible environmental damage.

Spatial estimates in this study imply that an inverted U-shape pattern also depends on the localities of the regions. EKC relationship should not be treated as an automatic process, but conditional on structural features, such as environmental awareness, education level, the use of environmental friendly resources, and other socioeconomic conditions. However, the unavailability of regional data on these location specific factors is the main limitation of this study, and remains a further research area for future studies as more data become available. 


\section{References}

AKBOSTANCI, E., Türüt-Aşık, S. and Tunç, İ.,“The Relationship between Income and Environment In Turkey: Is There an Environmental Kuznets Curve?”, Energy Policy, 37(3), 2009, pp.861-867.

ANSELIN, L. and Florax, R. J.,Small Sample Properties of Tests for Spatial Dependence in Regression Models: Some Further Results, In New Directions in Spatial Econometrics, ed. Luc Anselin and Rey Florax, Berlin, Springer-Verlag, 1995, pp. 21-74.

ANSELIN L. and Florax, R. J.,Advancesin Spatial Econometrics. Methodology, Tools and Applications. Berlin, Springer-Verlag, 2004.

ANSELIN, L.,Spatial Econometrics: Methods and Models, Dordrect, The Netherlands, Kluwer, 1988.

ANSELIN, L., Spatial Econometrics, In Palgrave Handbook of Econometrics, ed. Terence C. Mills and Kerry Patterson, Basingstoke, Palgrave McMillan, 2006.

ASGHARI, M., "Environmental Kuznets Curve and Growth Source in Iran”, Panoeconomicus, 59(5), 2012, pp. 609-623.

CARSON, R. T., Yongil, J. and McCubbin, D. R. "The Relationship between Air Pollution Emissions and Income: US data”, Environment and Development Economics, 2(4), 1997, pp. 433-450.

DASGUPTA, S., Laplante, B., Wang, H. and Wheeler, D. “Confronting the Environmental Kuznets Curve.”, Journal of Economic Perspectives, 16(1), 2002, pp. 147-168.

DINDA, S., "Environmental Kuznets Curve Hypothesis: A Survey", Ecological Economics, 49(4), 2004, pp. 431-455.

ELHORST, P., “Specification and Estimation Panel Data Models", International Regional Review, 26(3), 2003, pp. 244-268.

ELGIN, C. and Öztunal, O., "Environmental Kuznets Curve for the Informal Sector of Turkey (1950-2009)", Panoeconomicus, 61(4), 2014, pp. 471-485.

FLORAX, R. J. G. M., Folmer H., and Rey, S.J., "Specification Searches In Spatial Econometrics: The Relevance of Hendry's Methodology”, Regional Science and Urban Economics, 33(23), 2003, pp. 557-579.

GROSSMAN, G. M. and Krueger,A. B., "Environmental Impacts of the North American Free Trade Agreement”, NBER Working paper, 3914, 1991.

KAYGUSUZ, K., "Energy Use and Air Pollution Issues in Turkey”, Clean, 35(6), 2007, pp. 539-547.

KARAÇUKA, M. and Çatık. A. N., "A Spatial Approach to Measure Productivity Spillovers of Foreign Affiliated Firms In Turkish Manufacturing Industries." The Journal of Developing Areas, 46 (2), 2012, pp. 65-83.

KELLER, W., “International Technology Diffusion”, Journal of Economic Literature, 42(3), 2004, pp. 752 782.

KUZNETS, S., "Economic Growth and Income Inequality”, American Economic Review, 45(1), 1955, pp.128.

LEE, L., "Asymptotic Distributions of Quasi-Maximum Likelihood Estimators for Spatial Autoregressive Models", Econometrica, 72(6), 2004, pp. 1899-1925.

LISE, W., "Decomposition of $\mathrm{CO}_{2}$ Emissions over 1980-2003 in Turkey", Energy Policy, 34 (14), 2006, pp.1841-1852.

MADDISON, D., "Environmental Kuznets Curves: A Spatial Econometric Approach", Journal of Environmental Economics and Management, 51(2), 2006, pp.218-230.

MADDISON, D., "Modeling sulphur emissions in Europe: A spatial econometric approach", Oxford Economic Papers, 59(4), 2007, pp. 726-743.

MEADOWS, D. H., Meadows, D. L., Randers, J. and. Behrens, W. W., The Limits to Growth, New York, Universe Books, 1972.

ÖZDİLEK, H. G., "An Analogy on Assessment of Urban Air Pollution in Turkey over the turn of the 
Millennium (1992-2001)", Environmental Monitoring and Assessment, 122(1-3), 2006, pp. 203219.

RUPASINGHA, A., Goetz, S. J., Debertin, D. L. and Pagoulatos, A., “The Environmental Kuznets Curve for US counties: A Spatial Econometric Analysis with Extensions”, Papers in Regional Science, 83, 2004, pp. 407-424.

SOYTAS, U. and Sar1, R., "Energy Consumption, Economic Growth, and Carbon Emissions: Challenges Faced by an EU Candidate Member", Ecological Economics, 68(6), 2007, pp. 1667-1675.

STERN, D. I., "Progress on the Environmental Kuznets Curve?", Environment and Development Economics, 3(2), 1998, pp.173-196.

STERN, D. I., "The Rise And The Fall of Environmental Kuznets Curve”, World Development, 32(8), 2004, pp. 1419-1439.

STERN, D. I., Common, M. S. and Barbier, E. B., "Economic Growth and Environmental Degradation: A Critique of the Environmental Kuznets Curve.” World Development, 24(7), 1996, pp. 1151-1160.

VINCENT, J. R., “Testing for Environmental Kuznets Curves within a Developing Country”, Environment and Development Economics, 2(4), 1997, pp. 417-431.

TSURAMI, T. and Managi, S., "Decomposition of the environmental Kuznets curve: scale, technique, and composition effects", Environmental Economics and Policy Studies, 11, 2010, pp. 19-36.

ZHENG, X., Yu, Y., Wang, J. and Deng, H., "Identifying the Determinants and Spatial Nexus of Provincial Carbon Intensity in China: A Dynamic Spatial Panel Approach", Regional Environmental Change 14, 2013, pp. 1651-1661. 